
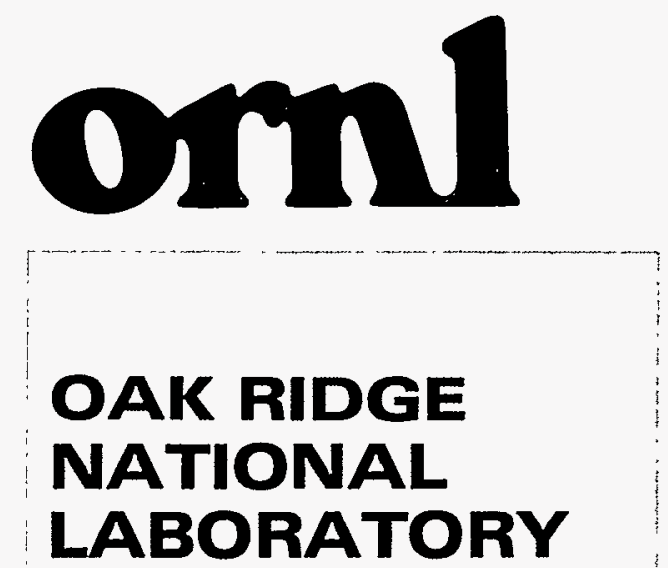

MARTIN MARUETRA
ORNL/TM-12965

\section{NUCLEAR MEDICINE PROGRAM PROGRESS REPORT FOR QUARTER ENDING MARCH 31, 1995}

\section{F. F. Knapp, Jr.}

\section{MANAGED BY}

MARTIN MARIETTA ENERGY SYSTEMS, INC. FOR THE UNITED STATES DEPARTMENT OF ENERGY
K. R. Ambrose
D. W. McPherson
A. L. Beets
S. Mirzadeh
H. Luo 
This report has been reproduced directly from the best available copy.

Available to DOE and DOE contractors from the Office of Scientific and Technical Information, P.O. Box 62, Oak Ridge, TN 37831; prices available from (615) 576-8401, FTS 626-8401.

Available to the public from the National Technical Information Service, U.S. Department of Commerce, 5285 Port Royal Rd., Springfield, VA 22161.

This report was prepared as an account of work sponsored by an agency of the United States Government. Neither the United States Government nor any agency thereof, nor any of their employees, makes any warranty, express or implied, or assumes any legal liability or responsibility for the accuracy, completeness, or usefulness of any information, apparatus, product, or process disclosed, or represents that its use would not infringe privately owned rights. Reference herein to any specific commercial product, process, or service by trade name, trademark, manufacturer, or otherwise, does not necessarily constitute or imply its endorsement, recommendation, or favoring by the United States Government or any agency thereof. The views and opinions of authors expressed herein do not necessarily state or reflect those of the United States Government or any agency thereof. 
ORNL/TM-12965

Contract No. DE-AC05-84OR21400

Health Sciences Research Division

NUCLEAR MEDICINE PROGRAM PROGRESS REPORT

FOR QUARTER ENDING MARCH 31, 1995

F. F. Knapp, Jr.
K. R. Ambrose
D. W. McPherson
A. L. Beets
S. Mirzadeh
H. Luo

Work sponsored by

DOE Office of Health and

Environmental Research

Date Published: June, 1995

\author{
OAK RIDGE NATIONAL LABORATORY \\ Oak Ridge, Tennessee 37831-6285 \\ managed by \\ MARTIN MARIEITA ENERGY SYSTEMS, INC. \\ for the \\ U.S. DEPARTMENT OF ENERGY
}




\section{DISCLAIMER}

Portions of this document may be illegible in electronic image products. Images are produced from the best available original document. 
Previous reports in this series:

ORNL/TM-5809

ORNL/TM-10294

ORNL/TM-5936

ORNL/TM-10377

ORNL/TM-6044

ORNL/TM-10441

ORNL/TM-6181

ORNLTM-10618

ORNL/TM-6371

ORNLITM-10711

ORNL/TM-6410

ORNLIM-10839

ORNLITM-6638

ORNL/TM-11014

ORNLITM-6639

ORNLTM-11043

ORNL/TM-6771

ORNLTM-11145

ORNL/TM-6916

ORNLITM-11224

ORNL/TM-6958

ORNLTM-11304

ORNL/TM-7072

ORNL/TM-7223

ORNLTM-7411

ORNLITM-11377

ORNL/TM-11427

ORNLTM-11550

ORNL/TM-7482

ORNLTM-11570

ORNLTM-7605

ORNLITM-11721

ORNLTM-7685

ORNL/TM-11755

ORNL/TM-7775

ORNL/TM-11830

ORNLITM-7918

ORNLTM-11881

ORNLITM-8123

ORNL/TM-11992

ORNL/TM-8186

ORNLTM-12054

ORNLTM-8363

ORNLTM-12110

ORNL/TM-8428

ORNL/TM-8533

ORNLITM-12159

ORNLITM-12222

ORNL/TM-12312

ORNL/TM-8619

ORNLTM-12343

ORNLITM-8746

ORNLITM-12411

ORNLITM-8827

ORNLTM-8966

ORNL/TM-9037

ORNL/TM-9124

ORNLTM-12485

ORNL/TM-12661

ORNLITM-12707

ORNLITM-12789

ORNL/TM-9343

ORNL/TM-12875

ORNL/TM-9394

ORNL/TM-12909

ORNL/TM-9480

ORNLITM-9609

ORNLTM-9707

ORNL/TM-9784

ORNL/TM-9937

ORNLTM-10082

ORNLTM-10238 


\section{CONTENTS}

Summary $\ldots \ldots \ldots \ldots \ldots \ldots \ldots \ldots \ldots \ldots \ldots \ldots \ldots \ldots \ldots \ldots$

Labeling of Anti-Granulocyte Antibody BW2501/186 with

Rhenium-188 for Potential Bone Marrow Ablation . . . . . . . . . . . . . . 6

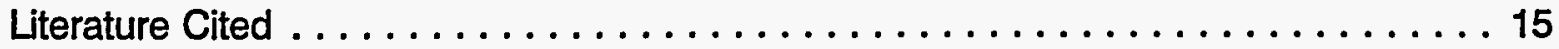

Other Nuclear Medicine Group Activities $\ldots \ldots \ldots \ldots \ldots \ldots \ldots \ldots \ldots$

Recent Publications $\ldots \ldots \ldots \ldots \ldots \ldots \ldots \ldots \ldots \ldots \ldots \ldots$

Presentations . . . . . . . . . . . . . . . . . . . 16

Medical Cooperative Shipments ....................... 17 


\section{Summary}

In this report the conditions for "direct" labeling of the anti-granulocyte (MAb) BW 250/183 monoclonal antibody with rhenium-188 (Re-188) from a generator are described." Re-188-BW $250 / 183$ is of interest for potential use for bone marrow ablation. The labeling time, temperature, $\mathrm{pH}$, and the amount of tin and citric acid were optimized utilizing IgG. Radiolabeling yields of greater than $97 \%$ were achieved using $1 \mathrm{~mL}$ of a phthalate/tartrate buffer (pH 5.M=?), $250 \mu \mathrm{g}$ BW 250/183, $1.0 \mathrm{mg}$ citric acid, $400 \mu \mathrm{g}$ tin (II) chloride, and $1 \mathrm{~mL}$ of the tungsten-188/rhenium188 generator eluent (200-800 $\mu \mathrm{Ci}$ of Re-188). Analysis of the Re-188-labeled IgG and BW 250/183 was performed by Instant Thin Layer Chromatography (ITLC), Sephadex purification and High Performance Liquid Chromatography (HPLC). When the labeling was performed at room temperature or $37^{\circ} \mathrm{C}$, in vitro stability studies performed in HSA solution, cysteine solution, $6 \underline{\mathrm{M}}$ urea solution and a $1 \%$ casein solution showed that the Re-188 label demonstrated a similar stability profile in all solutions. Initial studies indicate that Re-188-BW $250 / 183$ retained $\sim 90 \%$ of immunoreactivity when compared to the technetium-99m labeled antibody prepared from the same kit.

During this period, several radioisotopes prepared in the ORNL HFIR were also supplied on a cost-recovery basis or provided to collaborators for ongoing collaborative projects. These include tin- $117 \mathrm{~m}$, processed tungsten-188 and the ORNL alumina-based tungsten-188/rhenium188 generators. 


\section{Labeling of Anti-Granulocyte Antibody BW 250/183 with Rhenium-188 for Potential Bone Marrow Ablation}

Rhenium-188 (Re-188) is an attractive isotope for the radiolabeling of monoclonal antibodies (MABs) for radioimmunotheraphy (RAIT) due to its intensive high energy $\beta^{-}$emission $\left(E_{\max }=2.12\right.$ $\mathrm{MeV}$ ) and a gamma photon ( $155 \mathrm{KeV}$ ) which can be imaged by routinely available gamma camera systems. Another attractive feature is the availability of carrier-free rhenium- 188 from a tungsten-188/rhenium-188 $\mathrm{W}-188 / \mathrm{Re}-188$ ) generator system, ${ }^{1}$ which permits preparation of MABs labeled with high specific activity Re-188. Rhenium chemistry is similar to technetium chemistry so that similar techniques utilizing either direct labeling to reduced disulfide groups or an indirect approach involving the use of a bifunctional chelate, have been developed. ${ }^{2}$ Due to higher radiolabeling yields and ease of the labeling of the direct method, this approach was investigated for radiolabeling of the anti-granulocyte MAB, BW 250/183, for the "Non-Specific Cross-Reacting Antigen 95 (NCA 95)" with Re-188. BW 250/183 has been directly labeled with technetium-99m (Tc-99m), is commercially available in kit form and is routinely used for the clinical evaluation of bone marrow anatomy and function, ${ }^{3}$ and therefore, Re-188 labeled BW 250/183 is of particular interest as a potential new radiopharmaceutical for use as a method for bone marrow ablation. These methods for Re-188 labeling of BW 250/183 are being developed by Dr. D. W. McPherson who is working through June 1995 as a Visiting Scientist with Professor S. N. Reske, M.D. in the Nuclear Medicine Department at the University of Ulm, Germany.

The labeling of BW 250/183 was investigated with "carrier-free" Re-188 from our aluminabased W-188/Re-188 generator. Due to the high cost of BW 250/183 the optimum radiolabeling parameters were evaluated utilizing human $\lg G$ as a model antibody. The use of $\lg G$ for the optimization of the labeling parameters initially involved the reduction of the disulfide linkages for the subsequent attachment of Re-188. We chose the pretinning method utilizing tin(II) chloride ${ }^{4}$ since we proposed to reduce the rhenium to the +5 oxidation state with tin(II) chloride and therefore no separation of the antibody from the initial reducing agent would be required. Once the initial labeling of IgG was successful, the minimum concentration of tin (Figure 1) and citric 
acid (Figure 2) required to achieve a high labeling efficiency were investigated. The effects of temperature (Figure 3), pH of the phthalate/tartrate buffer (Figure 4), and concentrations of the reactants solution (Figure 5) were then investigated.

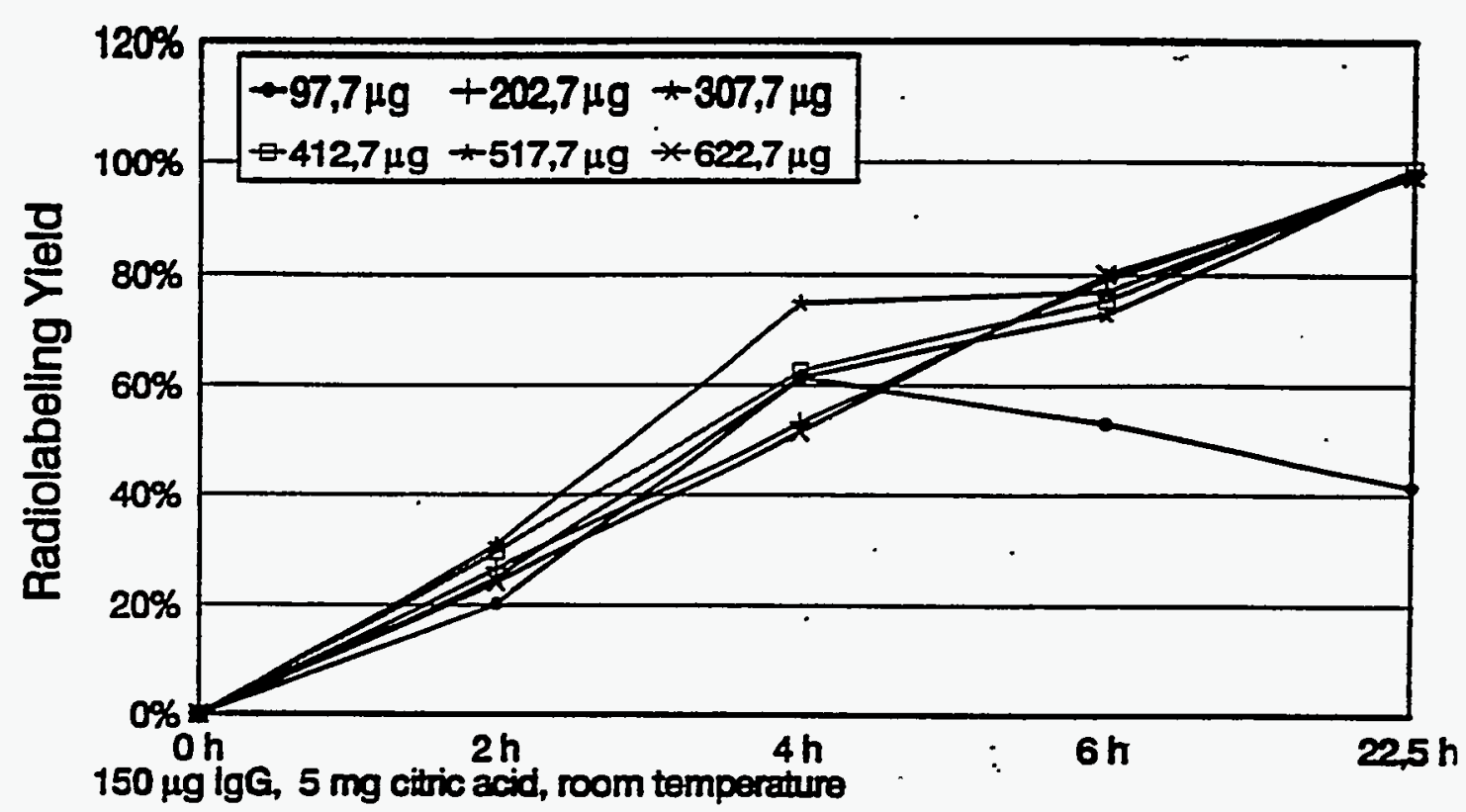

Figure 1 - Effects of stannous concentration on MAB labeling

It was observed from these studies that a labeling efficiency of $>97 \%$ was obtained with at least $200 \mu \mathrm{g}$ of tin(II) chloride. The amount of citric acid did not change the radiolabeling yield; therefore, the tin(II) chloride was dissolved in a minimum amount of citric acid ( $\sim 5 \mathrm{mg} / \mathrm{ml}$ ). For the reaction (Figure 2) where no citric acid was added, a minimum volume of concentrated $\mathrm{HCl}(10 \mu \mathrm{L})$ was added to dissolve the tin(II) chloride. The $\mathrm{pH}$ of the buffer was observed to have an important role in the rate of the labeling. When the $\mathrm{pH}$ of the phthalate/tartrate buffer was adjusted to 4.6 (the pH of the labeling solution was measured at 3.3), the reaction proceeded 
rapidly with a $>97 \%$ yield after 4 hours. However, since a low $\mathrm{pH}$ may have a detrimental effect on the immunoreactivity of the MAB, the adjustment of the buffer to $\mathrm{pH} 5.6(\mathrm{pH} 4.2$ labeling solution) was chosen for the subsequent labeling of BW 250/183. In addition, when the concentration of reactants was decreased by increasing the total volume of the labeling solution to $4.5 \mathrm{~mL}$, the labeling of the antibody was slower, requiring heating at $37^{\circ} \mathrm{C}$ overnight to achieve a high yield. It was also observed that increasing the concentration of IgG did not affect the labeling time. An important observation from these studies demonstrates that care must be taken to exclude air to minimize oxidation of Re back to the +8 oxidation state which does not bind to the MAB (Figure 6).

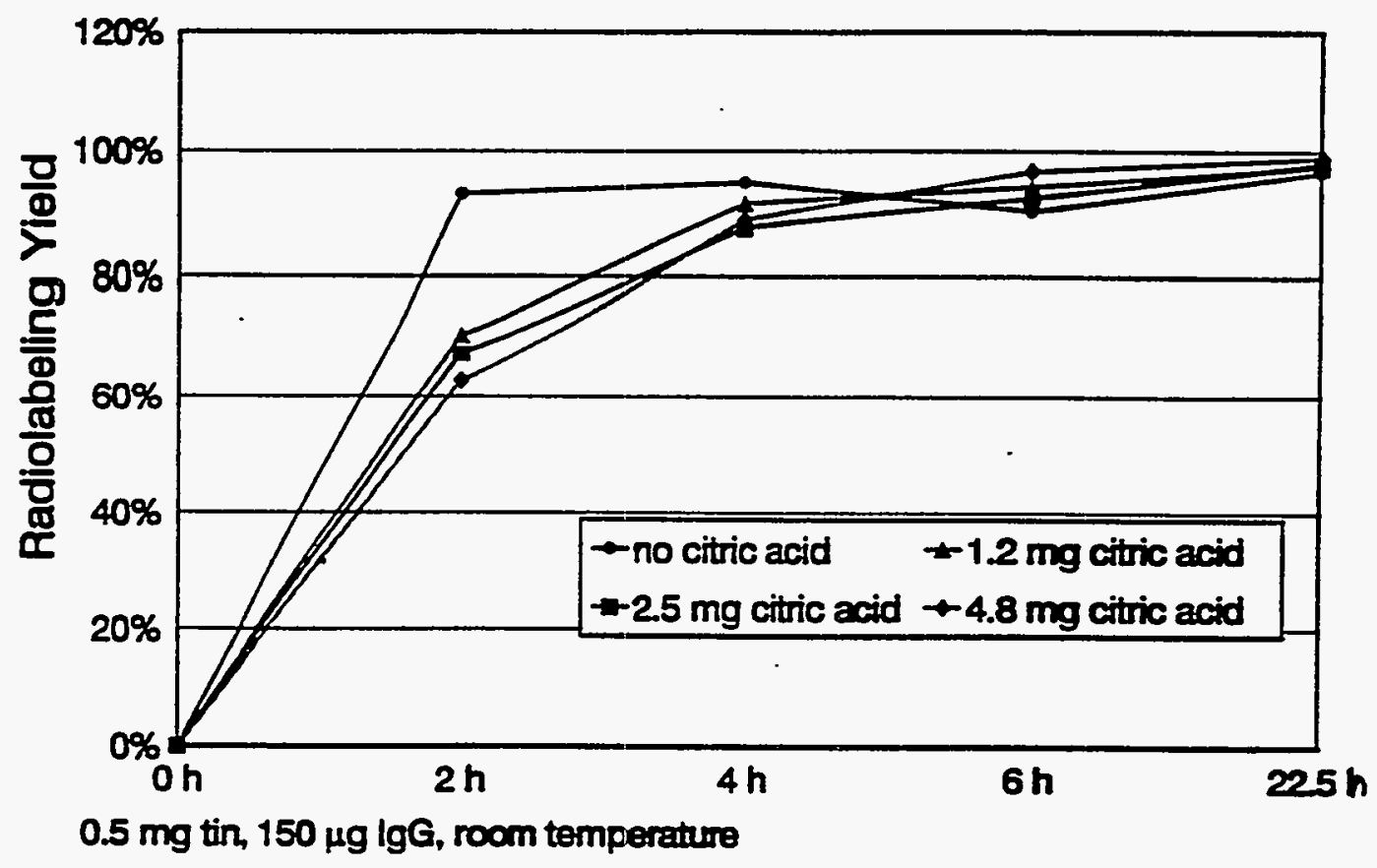

Figure 2 - Effects of citric acid concentration on MAB labeling 
In a typical labeling procedure of the MAB with Re-188, the following conditions were utilized. Saline and phthalate/tartrate buffer were purged with nitrogen for at least two hours prior to use, and all labeling reactions were performed under nitrogen. Tin(II) chloride (2 mg) and citric acid $(5 \mathrm{mg})$ were dissolved in $1 \mathrm{~mL}$ of a $40 \mathrm{mM} \mathrm{K}-\mathrm{H}$ phthalate/10 $\mathrm{mM} \mathrm{K-Na}$ tartrate buffer (pH 5.6). BW 250/183 (1.0 mg, vial 2 from kit, Behring) or lgG (1 mg) was dissolved in $1 \mathrm{~mL}$ of the phthalate/tartrate buffer. $250 \mu \mathrm{L}$ of the antibody solution, $200 \mu \mathrm{L}$ of the tin/citric acid solution, and $1.0 \mathrm{~mL}$ of the eluent from the $\mathrm{W}-188 / \mathrm{Re}-188$ generator (200-800 $\mu \mathrm{Ci})$, which had been purged with nitrogen for 5 minutes directly prior to use, were added to a nitrogen- purged glass reaction vial. The vial was sealed under nitrogen and set allowed to stand at room temperature or heated in a constant water bath at $37^{\circ} \mathrm{C}$ for the desired time. The labeling yield was determined by ITLC analysis using $2 \mathrm{M}$ urea as the mobile phase.

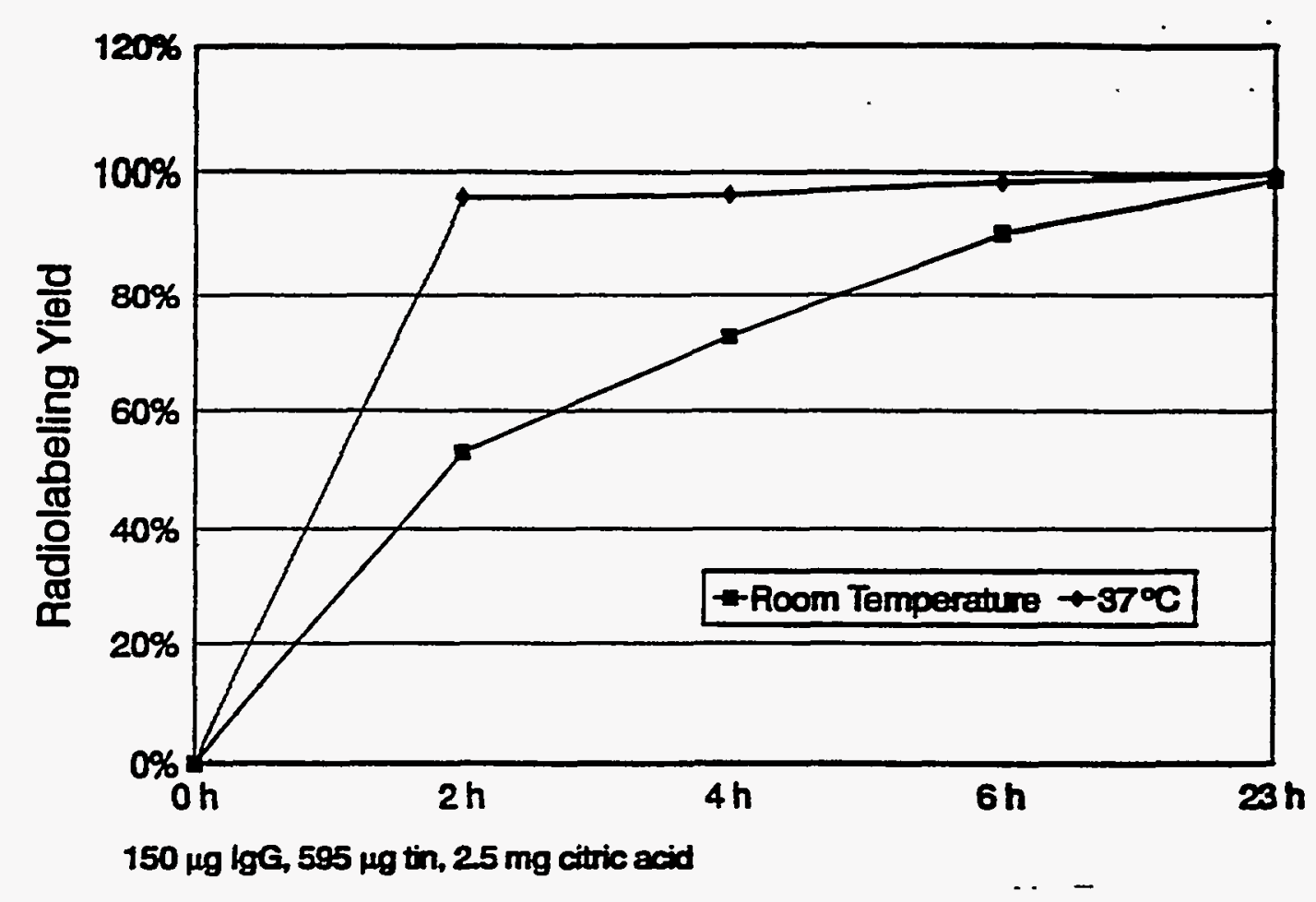

Figure 3 - Effect of temperature on MAB labeling 
Control experiments in which Re-188 was reacted with IgG or with tin demonstrate the absence of non-specific binding of Re-188 to $\mathrm{lgG}$ and formation of Re-colloids. Analysis of the Re-188-BW 250/183 by "HSA soaked" ITLC sheets also confirms the absence of Re-colloid formation under the labeling conditions utilized. The radiolabeling of IgG was also performed in a 350 fold excess of iodoacetate and the labeling of $\mathrm{lgG}$ was $95 \%$ blocked after 4 hours. This datum indicates that the attachment of the Re-188 is occurring at the reduced sulfide linkages. An initial attempt to label the antibody directly in the vial from the kit by the addition of tin-buffer solution ( $400 \mathrm{mg} / 0.2 \mathrm{~mL}$ ) and $\mathrm{Re}-188$ from the generator afforded only a modest labeling yield of $60 \%$ after 24 hours at room temperature. This low yield may be due to the inability to exclude air from the vial or to the high $\mathrm{pH}$ of the labeling solution since the vial from the kit contains 2 mg sodium phosphate.

In vitro stability studies were performed by incubating the Re-188-BW 250/183 or IgG with an excess of various challenge solutions at $37^{\circ} \mathrm{C}$ and monitoring the solution by ITLC at designated intervals (Table 1). It was observed that IgG and BW 250/183 demonstrated similar in vitro stability when labeling was performed at room temperature and $37^{\circ} \mathrm{C}$. In addition the in vitro stability was similar for IgG and BW 250/183. It was also observed that if the labeling solution containing Re-188-MAB was allowed to stand at room temperature for up to 48 hours, Re-188 remained attached to the MAB. 


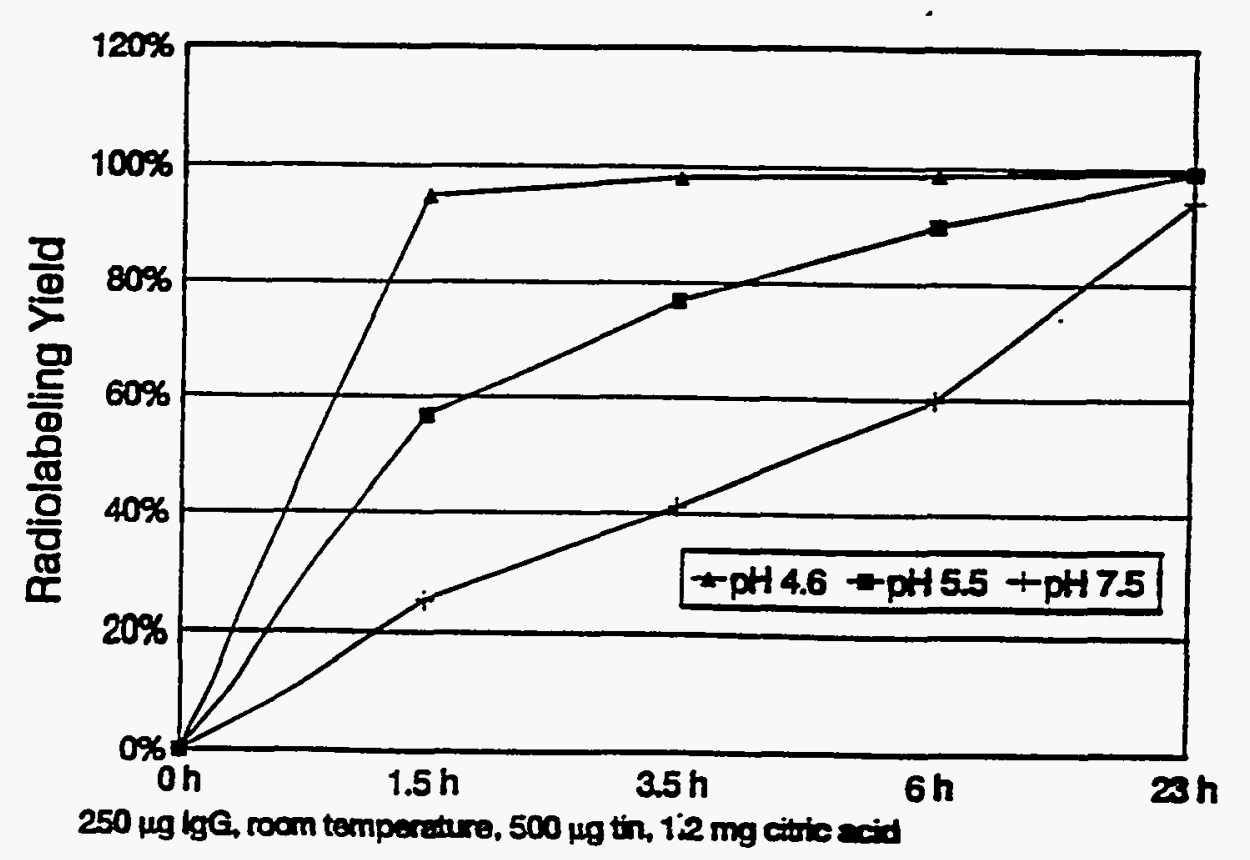

Figure 4 - Effects of $\mathrm{pH}$ on MAB labeling

HPLC analysis [Waters Protein Pak 300SW column, 0.1M $\mathrm{K}_{2} \mathrm{HPO}_{4}(\mathrm{pH} 7.0)$ ] was performed with Re-188 BW 250/183 and IgG, and no unbound Re-188 was observed, confirming the ITLC results which indicated a labeling efficiency of $>97 \%$. However, the Re-188 was readily removed from the antibody by the column, and the activity was released slowly from the column. Control experiments confirmed $\mathrm{Re}-188$ in the +8 oxidation state was not binding to the column. In addition, there was observed to be $\sim 7 \%$ of high molecular weight components formed during the labeling procedure. Sephadex G-50-150 column purification was also performed on Re-188IgG. There was no unbound Re-188 detected, and purified Re-188-IgG was obtained. However 
as observed in the HPLC analysis, the recovery of radioactivity from the purification procedure was $\sim 60 \%$, indicating that the Re-188 is again removed from the labeled $\mathrm{lgG}$.

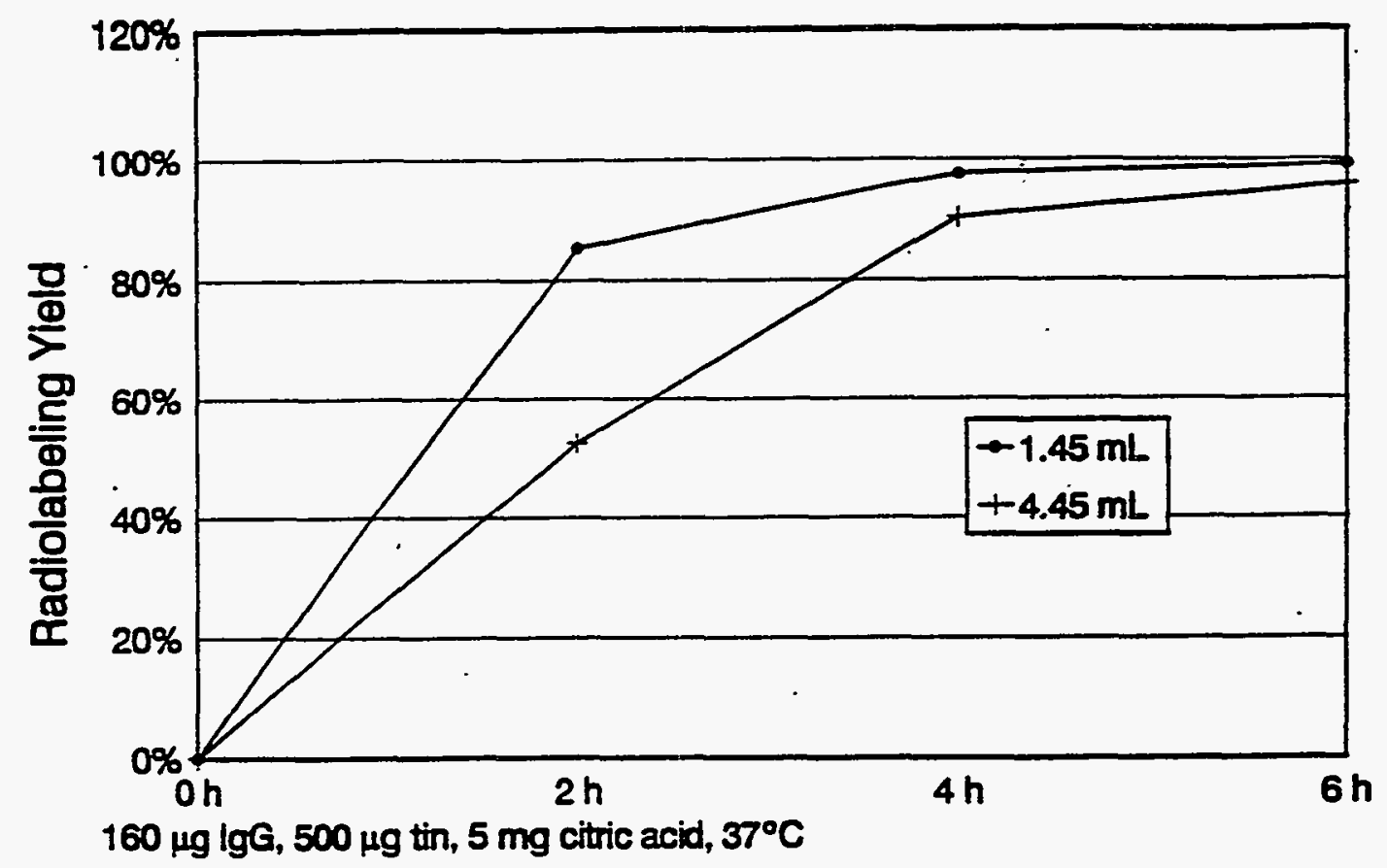

Figure 5 - Effects of reactant concentration on MAB labeling

The immunoreactivity of Re-188-BW 250/183 was determined by incubation of labeled $M A B$ with antigen containing material (ACM) followed by centrifugation, washing, and counting pellet and supernatant to determine ACM-bound to free Re-188. These studies indicate that the immunoreactivity of BW $250 / 183$ when labeled at room temperature is not markedly different from that when the labeling is performed $37^{\circ} \mathrm{C}$. In addition Re-188-BW $250 / 183$ retained $\sim 90 \%$ of immunoreactivity as compared to TC-99m-BW 250/183 prepared by the same kit. 


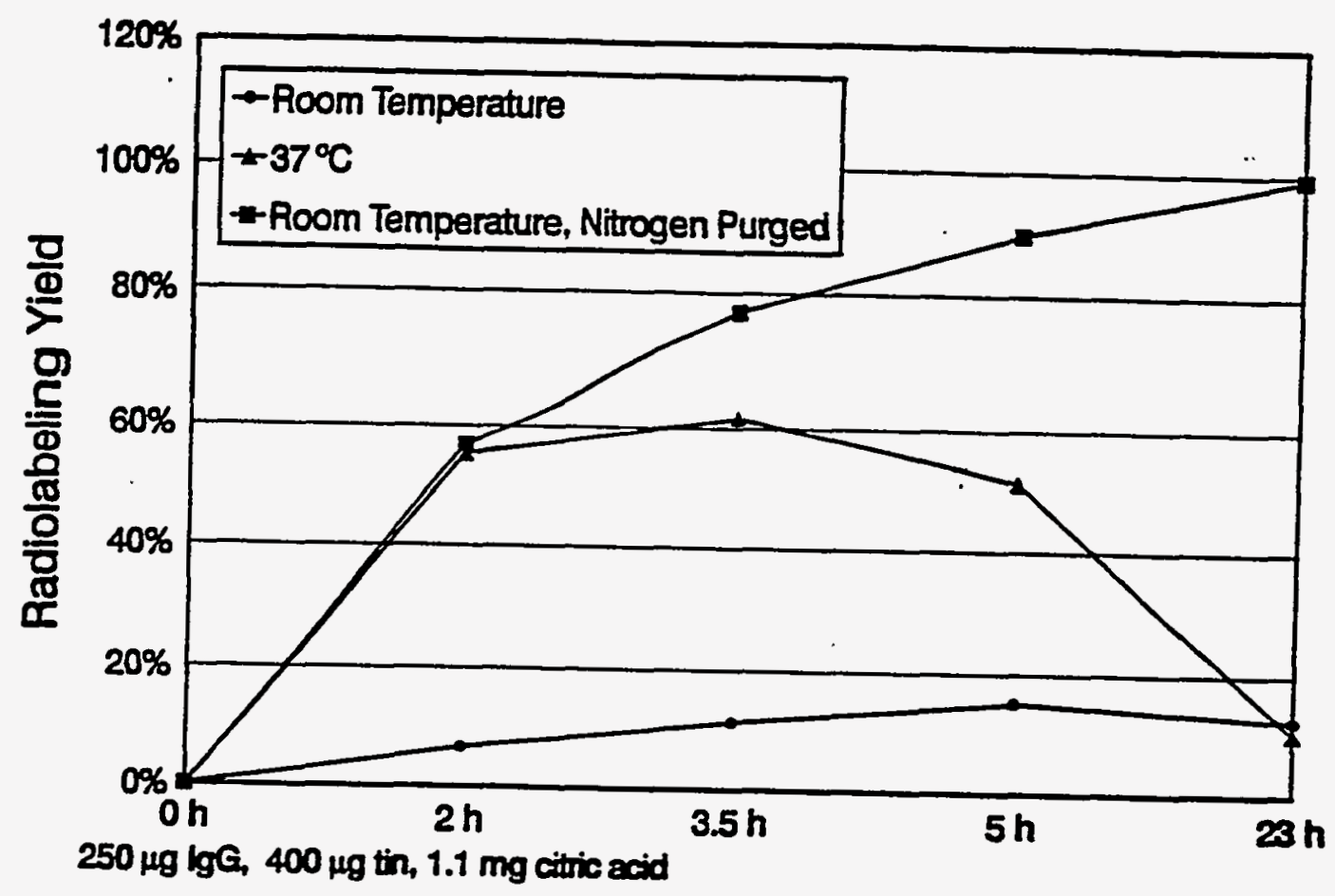

Figure 6 - Effects of temperature and presence of oxygen on MAB labeling

In summary, the anti-granulocyte MAB BW 250/183 has been labeled with generatorproduced Re-188. The use of $400 \mu \mathrm{g}$ of tin(II) chloride, $1 \mathrm{mg}$ citric acid and a phthalate/tartrate buffer ( $\mathrm{pH}$ 5.6) afforded a labeling efficiency of $>97 \%$ after 6 hours at $37^{\circ} \mathrm{C}$ or 24 hours at room temperature. In vitro stability tests indicate no difference in the stability of the antibody between the labeling performed at room temperature or $37^{\circ} \mathrm{C}$. Initial immunoreactivity tests demonstrated that the antibody retains 90\% of the TC-99m-BW $250 / 183$ immunoreactively from the same kit. Therefore this simple radiolabeling method allows for the preparation of Re-188-BW 250/183 with high specific activity for potential use in bone marrow ablation studies. 
Table 1. In Vitro Stability of Re-188-lgG and BW 250/183

Re-188-IgG

Cysteine/lgG (3500:1)HSA/lgG (1700:1)1\% Casien/lgG (1:1, v/v)

\begin{tabular}{|c|c|c|c|c|c|c||}
\hline Time $(\mathrm{h})$ & $\mathrm{RT}$ & $37^{\circ} \mathrm{C}$ & $\mathrm{RT}$ & $37^{\circ} \mathrm{C}$ & $\mathrm{RT}$ & $37{ }^{\circ} \mathrm{C}$ \\
\hline 1 & $98.9 \%$ & $98.4 \%$ & $99.7 \%$ & $99.7 \%$ & $99.7 \%$ & $99.5 \%$ \\
\hline 2.5 & $98.0 \%$ & $92.2 \%$ & $99.7 \%$ & $99.4 \%$ & $99.4 \%$ & $99.3 \%$ \\
\hline 6.5 & $95.0 \%$ & $81.6 \%$ & $99.0 \%$ & $99.2 \%$ & $99.6 \%$ & $99.3 \%$ \\
\hline 23 & $79.8 \%$ & $60.2 \%$ & $98.0 \%$ & $94.6 \%$ & $93.0 \%$ & $82.1 \%$ \\
\hline
\end{tabular}

Incubation of Re-188-lgG in $6 \underline{M}$ Urea

\begin{tabular}{|c|c|c|}
\hline Time (hours) & RT & $37^{\circ} \mathrm{C}$ \\
\hline 1.5 & $98.0 \%$ & $99.6 \%$ \\
\hline 4.5 & $94.2 \%$ & $96.1 \%$ \\
\hline 8.0 & $82.3 \%$ & $89.8 \%$ \\
\hline 23.5 & $44.9 \%$ & $55.2 \%$ \\
\hline
\end{tabular}

Re-188-BW 250/183

Cysteine/MAB (6500:1) HSA/MAB (250:1) HSA/lgG (500:1)

\begin{tabular}{|c|c|c|c|c|c||}
\hline \hline Time (h) & RT & $37^{\circ} \mathrm{C}$ & RT & $37^{\circ} \mathrm{C}$ & $37^{\circ} \mathrm{C}$ \\
\hline 1.5 & $81.8 \%$ & $91.2 \%$ & $95.8 \%$ & $98.9 \%$ & $99.6 \%$ \\
\hline 4.5 & $70.9 \%$ & $72.8 \%$ & $89.6 \%$ & $95.7 \%$ & $99.1 \%$ \\
\hline 6.5 & $62.7 \%$ & $66.4 \%$ & $89.1 \%$ & $93.4 \%$ & $99.6 \%$ \\
\hline 22.5 & $29.6 \%$ & $39.8 \%$ & $79.5 \%$ & $89.3 \%$ & $87.0 \%$ \\
\hline
\end{tabular}

Solutions were incubated $37^{\circ} \mathrm{C}$ and analyzed by ITLC. Results given as $\%$ Re-188 with MAB. $\mathrm{RT}=$ room temperature. 


\section{Literature Cited}

1. Callahan, A. P., Rice, D. E., Knapp, F. F., Jr. "Re-188 for Therapeutic Applications from an Alumina Based W-188/Re-188 Radionuclide Generator System," NucCompact, 20, 3 (1989).

2. Griffiths, G. L., Goldenburg, D. M., Jones, A. L, Hansen, H. j., "Radiolabeling of Monoclonal Antibodies and Fragments with Technetium and Rhenium," Bioconjugate Chem., 3, 91 (1992).

3. Reske, S. N. "Recent Advances in Bone Marrow Scanning," Eur. J. Nucl. Med., 108, 203 (1991).

4. Rhodes, B. A., Torvestad, D. A., Breslow, K.,Burchiel, S. W., Reed, K. A., Austin, R. K. ${ }{ }^{199 \mathrm{~m}}$ Tc-Labeling and Acceptance Testing of Radiolabeled Antibodies and Antibody Fragments," in Tumor Imaging: The Radioimmunochemical Detection of Cancer, Burcheil, S. W., Rhodes, B. A., Friedman, B., eds. New York, Masson Publishing USA, Inc., pp 111123 (1984). 


\section{Other Nuclear Medicine Group Activities}

\section{Publications}

E. Dadachova, S. Mirzadeh, R. M. Lambrecht, E. L. Hetherington and F. F. (Russ) Knapp, Jr., "Separation of Carrier-Free Holmium-166 from Dysprosium Oxide Targets by Partition Chromatography and Electrophoresis," J. Radioanalyt. Nucl. Chem. Lett., 199, 115-123 (1995).

F. F. (Russ) Knapp, Jr., A. P. Callahan, A. L. Beets, S. Mirzadeh and B.-T. Hsieh,

"Processing of Reactor-Produced ${ }^{188} \mathrm{~W}$ for Fabrication of Clinical Scale Alumina-Based ${ }^{188} W /{ }^{188} \operatorname{Re}$ Generators," Appl. Radiat. Isot., 45, 1123-1128 (1994).

F. C. Visser, J. J. Bax and F. F. Knapp, Jr., "Single-Photon Imaging of Myocardial Metabolism: The Role of ${ }^{123}$-Labelled Fatty Acids and ${ }^{18}$ F Fluorodeoxyglucose," In, Nuclear Medicine in Clinical Diagnosis and Treatment, Volume 2 of two volumes, Churchill Livingstone, Edinburg-London, 1994, 1239-1248 (1994).

\section{Presentations}

On January 19-22, Dr. S. Mirzadeh participated in the Symposium on Nuclear Oncology: Advances in Diagnosis and Therapeutic Applications, held in Key Biscayne, Florida and presented a paper describing the unique production capabilities of the ORNL High Flux Isotope Reactor (HFIR) of Several Radioisotopes of Current Widespread Interest for Therapy: 
S. Mirzadeh, A. L. Beets and F. F. Knapp, Jr., "Reactor-Produced Radioisotopes for Cancer Therapy and Bone Pain Palliation."

H. Luo, a Hollaender Distinguished Postdoctoral Fellow working in the Nuclear Medicine Group, participated in the 12th Winter Fluorine Conference sponsored by the American Chemical Society held in St. Petersburg, Florida, on January 22-27, and presented the following paper describing new fluorinated receptor agents:

H. Luo, D. W. McPherson and F. F. Knapp, Jr., "Synthesis of 1-Azabicyclo[2.2.2]oct-3-yl ahydroxy- $\alpha$-phenylacetate ("FQNPE")- a New Ligand for Radiolabeling with Fluorine-18 for the Potential Imaging of Muscarinic Receptors by PET."

\section{Medical Cooperative Shipments}

During this period several radioisotopes prepared in the ORNL High Flux Isotope Reactor (HFIR) were supplied through collaborative arrangements and on a cost recovery basis. A processed tungsten-188 solution was provided to the Australian National Science and Technology Organization (ANSTO) on a cost-recovery basis. Tin-117m was supplied to the Medical Department at Brookhaven National Laboratory for preparation of tin-117m-DTPA for further clinical trials for bone pain palliation. Through a Cooperative Research and Development Agreement (CRADA), tungsten-188/rhenium-188 generators were provided to RhoMed, Inc. (B.A. Rhodes, Ph.D.) and the Clinic for Nuclear Medicine at the University of Bonn, Germany (Prof. H.J. Biersack, M.D., and co-workers), for radiolabeling and testing of peptides for cancer therapy. Tungsten-188/rhenium-188 generators were also provided to the Departments of Nuclear Medicine at the University of Ulm, Germany (Prof. S. N. Reske, M.D.) and the University of Nantes, France (Prof. J. F. Chatal, M.D. and M. Hosono, M.D., Ph.D.). 
ORNL/TM-12965

\section{INTERNAL DISTRIBUTION}

1. C. W. Alexander

2. K. R. Ambrose

3. A. L. Beets

4. B. A. Berven

5. E. D. Collins

6. K. F. Eckerman

7-11. F. F. Knapp, Jr

12. H. Luo

13. D. W. McPherson

14. S. Mirzadeh

15. B. Patton

16. C. L. Ottinger
17. G. Prosser

18. D. E. Reichle

19. P. S. Rohwer

20. R. E. Swaja

21. S. J. Wolfe

22-24. Central Research Library

25. Document Record Section

26-28. Laboratory Records Dept

29. Lab Records, ORNL - RC

30. ORNL Patent Section

\section{EXTERNAL DISTRIBUTION}

31. S. James Adelstein, M.D., Department of Radiology, Harvard Medical School, Boston, MA 02115

32. H. L. Atkins, M.D., Radiology Dept., State Univ. of New York, Stony Brook, NY 11794-8460

33 H. J. Biersack, M.D., Director, Klinik fuer Nuklear Medizin, Der Universitaet Bonn, Sigmund Freud Strasse 25, 53127, Bonn 1, Germany

34. A. Bockisch, Ph.D., M.D., Klinik und Poliklinik fuer Nuklearmedizin, Postfach 3960 , Langenbeckstrasse 1, 55101 Mainz, Germany

35. C. Brihaye, Centre de Recherches du Cyclotron, Universite de Liege, Belgium

36. A. B. Brill, M.D., Ph.D., Dept. of Nuclear Medicine, Univ. of Massachusetts Medical Center, 55 Lake Avenue North, Worcester, MA 01655

37. T. F. Budinger, M.D., MS 55/121, Lawrence Berkeley Laboratory, 1 Cyclotron Road, Berkeley, CA 94720

38. A. P. Callahan, Route 1, Box 305, Harriman, TN 37748

39. D. Cole, Medical Applications and Biophysical Research Division, ER-73, Department of Energy, GTN, Washington, D.C. 20585-1290

40. B. Coursey, National Institute for Standards and Technology, Building 245, RM C214 Gaithersburg, MD 20899

41. J. G. Davis, M.D., Medical and Health Sciences Division, ORAU, Oak Ridge, TN 37831 
42. R. F. Dannals, Division of Nuclear Medicine, Johns Hopkins Medical Institutions, Baltimore, MD 21205-2179

43. S.J. DeNardo, M.D., University of California, Davis Medical Center, 4301-X Street, FOCB II-E Sacramento, CA, 95817

44. R. Dudczak, M.D., Dept. Nuclear Medicine, I. Medizinische Universitatsklinik, A-1090 Wien, Lazarettgasse 14, Vienna, Austria

45. G. Ehrhardt, Missouri University Research Reactor, University of Missouri, Research Park, Columbia, MO 65211

46. D. R. Elmaleh, Physics Research Dept., Massachusetts General Hospital, Boston, MA 02114

47. L. Feinendegen, Medical Department, Brookhaven National Laboratory, Upton, NY 11973

48. A. Fritzberg, NeoRx Corporation, 410 West Harrison, Seattie, WA 98119

49. D. M. Goldenberg, M.D., Center of Molecular Medicine and Immunology, 1 Bruce Street, Newark, NJ 07103

50. G. Goldstein, DOE-OHER, Washington, DC 20585

51. G. Griffiths, Immunomedics, Inc., 300 American Rd, Morris Plains, NJ 07950

52. J. Hiltunen, Managing Director, MAP Medical Technologies, Inc., Elementtitie 27, SF-41160 Tikkakoski, Finland

53. Bor-Tsung Hsieh, Ph.D., Institute of Nuclear Energy Research, (INER) Lung-Tan, Taiwan, Republic of China

54. K. Hubner, M.D., Department of Radiology, UT Memorial Hospital, Knoxville, TN 37920

55. J. M. R. Hutchinson,Ph.D., U. S. Dept. of Commerce, National Institute of Standards and Technology, Gaithersburg, MD 20899-0001

56. B. Johannsen, Ph.D., Forschungszentrum Rossendorf e.V.Postfach 5101 19, D-01314 Dresden, Federal Republic of Germany.

57. A. Jones, HMS Radiology Dept., Shields Warren Radiation Laboratory, 50 Binney Street, Boston, MA 02115

58. G. W. Kabalka, Chemistry Department, University of Tennessee, Knoxville, TN 37996-1600

59. G. Kirsch, Department of Chemistry, Universite de Metz, Metz, France

60. J. Kropp, M.D., Klinik fur Nuklearmedizin, der Medizinischen Akademie, Fetscher - Str. 74, 01307 Dresden, Germany

61. D. E. Kuhl, M.D., Division of Nuclear Medicine, University of Michigan Hospitals, University Hospital BIG 412/0028, 1500 E. Medical Center Drive, Ann Arbor, MI 48109-0028

62. C. Lambert, 119 Montclair Blvd., Savannah, GA 31419

63. S. Larson, M.D., Sloan-Kettering Inst. for Cancer Research, New York, NY 10021

64. E. C. Lisic,Ph.D., Department of Chemistry, Tennessee Technological University, Cookeville, Tennessee 38505

65. J. Lister-James, Ph.D., Director, Research Administration, Diatech, Inc., 9 Delta Drive, Londonderry, New Hampshire 03053

66. O. Lowe, Isotope Production and Distribution Program, U.S. Department of Energy, NE-46, GTN, Room B-419, Washington, D. C. 20585-1290

67. G. Limouris, Nuclear Medicine Department, Areteion University Hospital, Athens Medical School, Athens, Greece 
68. D. J. Maddalena, FRACl, Department of Pharmacology, Sydney University, NSW 2006, Sydney, Australia

69. John Maddox, 4608 Flower Valley Drive, Rockville, MD 20853-1733.

70. H.-J. Machulla, Eberhard-Karls-Universität Tübingen, Radiologische Universitätsklinik, PetZentrum, Röntgenweg 11, 7400 Tübingen, Germany

71. Frederick J. Manning, National Academy of Sciences, Institute of Medicine, 2101 Constitution Ave., M.W., Washington, D.C. 20418

72. M. Meyer, M.D., Biomedical Research Foundation, P.O. Box 38050, Shreveport, LA 711338050

73. Office of Assistant Manager for Energy Research and Development DOE-ORO, Oak Ridge, TN 37831

74. G. Notohamiprodjo, M.D., Ph.D., Institute of Nuclear Medicine, Heart Center North RhineWestphalia, Bad Oeynhansen, D-4970, Germany

75. C. L. Partain, M.D., Professor and Vice Chairman, Dept. Radiology and Radiological Sciences, Vanderbilt University Medical Center, Nashville, TN 37232

76. R. C. Reba, M.D., Department of Radiology, 5841 S. Maryland Ave., MC 2026, Chicago, IL 60637

77. S. N. Reske, M.D., Klinik für Nuklearmedizin, Arztlicher Direktor der Nuklearmedizin, Klinikum der Universität Ulm Oberer Eselsberg, D-7900, Ulm, Germany

78. M. P. Sandler, M.D., Chief, Nuclear Medicine Section, Vanderbilt University Medical Center, Nashville, TN 37232

79. R. E. Schenter, HO-37, Westington Hanford Co., P.O. Box 1970, Richland, WA 99352

80. A. Serafini, Nuclear Medicine Division (D-57), University of Miami School of Medicine, P. O. Box 016960, Miami, FL 33101

81. S. K. Shukla, Prof., Servizio Di Medicina Nucleare, Ospedale S. Eugenio, Pizzale Umanesimo, 10, Rome, Italy

82. S. Smith, Biomedicine \& Health Program, Australian Nuclear Sci. \& Tech. Org., Lucas Heights Research Laboratories, Private Mail Bag 1, Menai NSW 2234, Australia

83. J. Smith, Ph.D., Research \& Development, DuPont Merck Pharmaceutical Company, 331 Treble Cove Rd., North Billerica, MA 01862

84. A. Solomon, M.D., UT MRCH, 1924 Alcoa Highway, Knoxville, TN 37920-6999

85. P. Som, DVM, Medical Department, BNL, Upton, NY 11973

86. P. C. Srivastava, DOE-OHER, Washington, DC 20585

87. S. C. Srivastava, BIdg. 801, Medical Dept., BNL, Upton, NY 11973

88. G. Strathearn, Isotope Products Laboratories, Inc., 3017 N. San Fernando Blvd., Burbank, CA, 91504.

89. H. W. Strauss, M.D., Division of Nuclear Medicine, Stanford University Medical Center, Room H0101, Stanford, California 94305-5281

90-91. Office of Scientific and Technical Information, DOE, Oak Ridge, TN 37831

92. E. A. van Royen, M.D., Ph.D., Head, Department of Nuclear Medicine, Academic Medical Center, University of Amsterdam, Meibergdreef 9, 1105 AZ Amsterdam ZO, The Netherlands. 
93. F. C. Visser, M.D., Cardiology Dept., Free University Hospital, De Boelelaan 117, Amsterdam, The Netherlands

94. H. N. Wagner, Jr., M.D., Div. of Nuclear Medicine, Johns Hopkins Medical Institutions, 615 N. Wolfe Street, Baltimore, MD 21205-2179

95. A.P. Wolf, Chemistry Department, Brookhaven National Laboratory, Upton, NY 11973

96. R. Wolfangel, Mallinckrodt, Inc., 675 McDonnell Blvd., P.O. Box 5840, St. Louis, MO 63134

97. J.-l. Wu, Ph.D., Senior Research Representative, Nihon Medi-Physics Co., Ltd., 2200 Powell Street, Suite 765, Emeryville, CA 94608.

98. S. Wynchank, Research Institute for Medical Biophysics (RIMB), Republic of South Africa

99. Y. Yonekura, M.D., Kyoto University Faculty of Medicine, Shogoin, Sakyo-kuy, Kyoto, 606-01, Japan 